\title{
Chemically Modified Carbon Paste Electrode for Determination of Cesium Ion by Potentiometric Method
}

\author{
Refat F. Aglan ${ }^{1 *}$, Gehad G. Mohamed ${ }^{2}$, Hala A. Mohamed $^{2}$ \\ ${ }^{1}$ Hot Laboratories Center, Atomic Energy Authority, Cairo, Egypt \\ ${ }^{2}$ Chemistry Department, Faculty of Science, Cairo University, Giza, Egypt

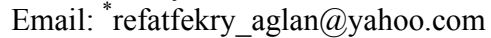

Received June 19, 2012; revised July 20, 2012; accepted July 29, 2012

\begin{abstract}
A new chemically modified carbon paste electrode for cesium(I) ion determination based on potassium zinc hexacyanoferrate (PZHCF) as an ionophore was prepared. The electrode exhibits a Nernstian response for Cs(I) ions over a wide concentration range from $1 \times 10^{-6}$ to $1 \times 10^{-1} \mathrm{~mol} \cdot \mathrm{L}^{-1}$ with a slope of $58 \pm 0.5 \mathrm{mV} \cdot \mathrm{decade}^{-1}$. It has a response time of about $35 \mathrm{~s}$ and can be used for a period of 3 months with good reproducibility. Detection limit obtained in the optimal conditions was $3 \times 10^{-7} \mathrm{~mol} \cdot \mathrm{L}^{-1}$. The potentiometric response is independent of the $\mathrm{pH}$ of the solution in the $\mathrm{pH}$ range $4.0-8.0$. The electrode possesses the advantages of low resistance, fast response over a variety of other cations. The proposed electrode is applied as a sensor for the determination of $\mathrm{Cs}(\mathrm{I})$ ion concentration in different samples solutions. The results showed a good correlation with the data obtained by atomic absorption spectrometric method.
\end{abstract}

Keywords: Cesium Determination; Modified Ion Selective Electrode; Potassium Zinc Hexacyanoferrate Ionophore

\section{Introduction}

Carbon paste electrodes (CPEs) are among the most popular types of carbon electrodes which have been widely used in electroanalysis, mainly due to such interesting properties as chemical inertness, low cost, wide potential window and suitable for a variety of sensing and detection application. The operational mechanism of the carbon paste electrodes depends on the properties of the modifier materials used to import selectivity towards the target species $[1,2]$. Such chemically modified carbon paste electrodes (CMCPEs) posses several advantages over the polymeric membrane ion selective electrodes, including ease of preparation, low ohmic resistance, low background contributions, renew ability, stable response and no need for an internal solution [3,4]. A number of potentiometric chemically modified carbon paste electrodes for the determination of different cations [5], anions $[3,6,7]$ and biologically important molecules $[4,8,9]$ have been reported. Modified carbon electrodes have been widely used as sensitive and selective sensors in various electroanalytical methods. Among the various mediators used for electrode modification, solid metal hexacyanoferrates (MHCFs) were used as suitable modifier due to excellent electron transfer properties. Therefore, various transition metal cations have been used with hexacyanoferrate to fabricate MHCF modified elec-

${ }^{*}$ Corresponding author. trodes. The selectivity of hexacyanoferrate(II) as ion exchangers for cesium makes hexacyanoferrate(II) an important exchange material for isolation and separation of cesium ion [1]. More stringent requirements are needed for the monitoring and determination of cesium ion in mineral rocks, thermal water in nuclear and industrial wastes, soil, plants, biological, and botanical samples. Various methods have been reported for cesium ion determination in aqueous and non-aqueous solutions including spectrophotometry [10], atomic absorption spectrometry [11,12], radioanalysis [13-15]. However, these methods required expensive instruments, well-controlled experimental conditions, and frequent maintenance and calibration. On the other hand, ion selective electrodes are versatile devices with a variety of chemical and medical applications in the analysis of inorganic [16-20] and organic ions [21,22]. Many areas of applied analytical chemistry such as process control, clinical, food, beverage, and environmental samples require a fast and simple method for the determination of the concentration of ionic species in aqueous systems. Potentiometric ion selective electrodes are considered as simple, quick, and inexpensive methods of analysis. Measurement of cesium ion concentration based on potentiometric sensors [2328 ] has been thoroughly investigated. However, a literature search showed that no ion selective carbon paste cesium electrodes based on potassium zinc hexacyanoferrate (PZHCF) as ionophore have been published to 
date. Therefore, a modified carbon paste electrode was used for potentiometric determination of cesium ion in pure and in different samples concentrations of laboratory made $\mathrm{CsNO}_{3}$ solutions and different real samples of water and simulated nuclear waste using PZHCF ion exchanger.

\section{Experimental}

\subsection{Reagents}

Solutions were prepared from a stock solution of 0.1 $\mathrm{mol} \cdot \mathrm{L}^{-1} \mathrm{Cs}(\mathrm{I})$ ion, prepared from a sufficient quantity of cesium nitrate (Merck) in bi-distilled water. The working solutions were prepared daily by suitable dilution of stock solution. All other solutions used in interference studies were prepared from analytical grade nitrate salts supplied from Merck. Graphite fine powder extra pure, dibutyl phthalate (DBP), dioctyl phthalate (DOP), dioctyl sebacate (DOS), tricresyl phosphate (TCP), o-nitrophenyloctyl ether (o-NPOE) were used as received from Aldrich.

\subsection{Preparation of Potassium Zinc Hexacyanoferrate(II)}

Potassium zinc hexacyanoferrate(II); $\mathrm{K}_{2} \mathrm{Zn}\left[\mathrm{Fe}(\mathrm{CN})_{6}\right]$, PZHCF, was prepared according to the method of Vasselaer et al. [29]. Saturated solution $\left(\sim 1 \mathrm{~mol} \cdot \mathrm{L}^{-1}\right)$ of potassium hexacyanoferrate(II) was mixed dropwise with 1 $\mathrm{mol} \cdot \mathrm{L}^{-1}$ zinc sulphate (volume ratio $1: 4$ ) under continuous stirring at room temperature. The precipitate was allowed to stand for 7 days, and then filtered. The precipitate was dried at $70^{\circ} \mathrm{C}$ for 2 days. After pulverizing, the precipitate was washed thoroughly with distilled water, filtered, dried again at $70^{\circ} \mathrm{C}$ for 2 days and ground to fine powder.

\subsection{Preparation of the Electrode}

A Teflon holder (12 cm length) with a hole at one end (7 $\mathrm{mm}$ diameter and $3.5 \mathrm{~mm}$ deep) for the carbon paste filling served as the electrode body. Electrical contact was made with a stainless steel rod through the center of the holder. This rod can move up and down by screw movement to press the paste down when renewal of the electrode surface is needed. Carbon paste was prepared by thoroughly mixing the potassium zinc hexacyanoferrate (II) ion exchanger $(20 \mathrm{mg})$ with graphite powder $(500$ $\mathrm{mg})$ and different plasticizers $(0.2 \mathrm{ml}$ of DOP, TCP, DBP, DOS or $o$-NPOE). Very intimate homogenization is then achieved by careful mixing using agate pestle and mortar and afterwards rubbed by intensive pressing with the pestle. The ready prepared paste is then packed into the hole of the electrode body the carbon paste was smoothed onto a wet filter paper until it had a shiny ap- pearance. The fabricated CPEs were conditioned in $10^{-4}$ $\mathrm{mol} \cdot \mathrm{L}^{-1} \mathrm{Cs}(\mathrm{I})$ solution for $2 \mathrm{hr}$. After several times of use, a fresh electrode surface can be obtained by squeezing out a small amount of the paste, scrapping off the excess against a conventional paper and polishing the electrode on a smooth paper to obtain a shiny appearance again. Unmodified carbon paste electrode was prepared in a similar fashion, without the addition of potassium zinc hexacyanoferrate in graphite powder and soaked in freshly prepared $10^{-4} \mathrm{~mol} \cdot \mathrm{L}^{-1} \mathrm{Cs}(\mathrm{I})$ solution.

\subsection{Apparatus}

Potential measurements were carried out at $25^{\circ} \mathrm{C} \pm 1{ }^{\circ} \mathrm{C}$ using a 692-pH meter (Metrohm). A techne circulator thermostat Model C-100 (Cambridge, England) was used to control the temperature of the test solution. A doublejunction silver-silver chloride reference electrode (Metrohm 6.0726.100) and cesium modified carbon paste as the indicator electrode. The carbon paste electrode was calibrated by immersion in conjunction with the reference electrode in a 50-ml beaker containing $10 \mathrm{ml}$ of $\mathrm{CsNO}_{3}$ solution of concentration ranging from $1 \times 10^{-1}$ to $1 \times 10^{-7} \mathrm{~mol} \cdot \mathrm{L}^{-1}$ was added with continuous stirring and the potential was recorded after stabilization to \pm 1.0 $\mathrm{mV}$. A calibration graph was then constructed by plotting the recorded potentials as a function of $\log [\mathrm{Cs}(\mathrm{I})]$. The resulting graph was used for subsequent determination of unknown cesium (I) ion concentration. In order to determine the reliability of the suggested electrode, it was used in the quantification of $\mathrm{Cs}(\mathrm{I})$ ion in some different concentrations of $\mathrm{CsNO}_{3}$ solutions. The tested samples were also determined by atomic absorption spectrometric method for comparison.

\subsection{Determination of $\mathrm{Cs}(\mathrm{I})$ Concentration in Simulated Nuclear Waste Solutions}

Two types of high level simulated active waste solutions designated as SIM 1 and SIM 2 were used for these experiments. Between these, only SIM 1 contained U(VI), while the compositions (Table 1) of the other metal ions were the same. As these solutions are highly acidic $(\sim 3$ $\mathrm{M} \mathrm{HNO}_{3}$ media), their pHs were brought up between 4 to 8 prior to the measurements. For the calibration purpose, high level simulated waste solutions were also prepared with the same composition and acidity without adding the Cs salt. The $\mathrm{Cs}(\mathrm{I})$ content in the original simulated waste solutions was determined with CMCP electrode employing three different procedures [30].

\section{Procedure 1:}

Eight well-cleaned $100 \mathrm{ml}$ glass beakers were numbered sequentially. Aliquots $(5 \mathrm{ml})$ of two sets of simulated waste solution were taken in duplicate in the beakers (nos. 1 - 4). Similarly, the waste solutions without Cs-salt 
Table 1. Composition of the simulated high level active waste.

\begin{tabular}{cccc}
\hline Element & $\begin{array}{c}\text { Concentration } \\
(\mathrm{g} / \mathrm{L})\end{array}$ & Element & $\begin{array}{c}\text { Concentration } \\
(\mathrm{g} / \mathrm{L})\end{array}$ \\
\hline $\mathrm{Fe}$ & 0.72 & $\mathrm{La}$ & 0.18 \\
$\mathrm{Cr}$ & 0.12 & $\mathrm{Pr}$ & 0.09 \\
$\mathrm{Ni}$ & 0.11 & $\mathrm{Nd}$ & 0.12 \\
$\mathrm{Na}$ & 5.5 & $\mathrm{Sm}$ & 0.086 \\
$\mathrm{~K}$ & 0.22 & $\mathrm{Cs}$ & 0.24 \\
$\mathrm{Mn}$ & 0.43 & $\mathrm{Y}$ & 0.06 \\
$\mathrm{U}$ & 6.34 & $\mathrm{Zr}$ & 0.004 \\
$\mathrm{Sr}$ & 0.03 & $\mathrm{Mo}$ & 0.14 \\
$\mathrm{Ba}$ & 0.06 & $\mathrm{Ce}$ & 0.06 \\
\hline
\end{tabular}

$(5 \mathrm{ml})$, prepared for calibration, were taken in another set of beakers numbers $(5-8)$. Aqueous $\mathrm{CsCl}$ solution $(3 \mathrm{ml}$, $\left.10^{-2} \mathrm{~mol} \cdot \mathrm{L}^{-1}\right)$ was added to the beakers 5 and 6 , while $\mathrm{CsCl}$ solution $\left(3 \mathrm{ml}, 10^{-3} \mathrm{~mol} \cdot \mathrm{L}^{-1}\right)$ was added to the beakers 7 and 8 . The solutions in all beakers were evaporated to dryness over a hot plate. After cooling to room temperature, de-ionized water $(5.0 \mathrm{ml})$ was added to each of the beakers, followed by heating to dryness again. The procedure was repeated two times. Finally, de-ionized water was added to the salts left over in beakers and diluted to $30 \mathrm{ml}$. The $\mathrm{pH}$ was measured and found to be in the range of 4 to 5 . The potential was measured with CMCP electrode.

\section{Procedure 2:}

Aliquots of simulated waste solutions without and with standard $\mathrm{CsCl}$ solutions were taken in eight beakers as mentioned in procedure 1. De-ionized water $(12 \mathrm{ml})$ and two drops of phenolphthalein solution were added to all the beakers. After neutralizing the solutions with 3 $\mathrm{mol} \cdot \mathrm{L}^{-1} \mathrm{LiOH}$ solution, the final volume was made up to $30 \mathrm{ml}$, and the potential was measured with $\mathrm{CMCP}$ electrode.

\section{Procedure 3:}

The $\operatorname{Cs}(\mathrm{I})$ concentration was determined by standard addition and subsequent dilution method. In this, $5.0 \mathrm{ml}$ aliquots from the two test simulated waste solutions in quadruplicates were taken in eight beakers. Aqueous $\mathrm{CsCl}$ solution $\left(3.0 \mathrm{ml}, 10^{-2} \mathrm{~mol} \cdot \mathrm{L}^{-1}\right)$ was added to the beakers numbers $3,4,7$ and 8 . All the solutions were neutralized with $3 \mathrm{~mol} \cdot \mathrm{L}^{-1} \mathrm{LiOH}$ and diluted to a final volume of $30 \mathrm{ml}$. The potential in all the solutions was measured with $\mathrm{CMCP}$ electrode. The solutions in beakers $3,4,7$ and 8 were further diluted with de-ionized water up to $60 \mathrm{ml}$, and the responses were measured.

\section{Results and Discussion}

\subsection{Optimization of the Modified Potassium Zinc Hexacyanoferrate Carbon Paste Electrode Composition}

In the preliminary experiments, potassium zinc hexacyanoferrate (PZHCF) was used as an electroactive material to prepare carbon paste electrodes for a variety of metal ions. The potential responses of the most sensitive electrodes, prepared under the same experimental conditions are shown in Figure 1. As it is seen, among different tested cations, Cs(I) with the most sensitive response seems to be suitably determined with the carbon paste electrode and the emf responses obtained for all other cations are much lower than that predicted by the Nernst equation. Also, carbon pastes with and without PZHCF were constructed. The carbon pastes with no PZHCF ionophor displayed insignificant selectivity toward cesium ion, and the response was not reliable, (Figure 2), whereas in the presence of the proposed modified electrode, the optimized carbon paste demonstrated a Nernstian response and remarkable selectivity for cesium ion over several common inorganic ions. Thus, this electrode composition was used for subsequent studies. The potential response of the optimized Cs(I) ions was examined. The average slope of the calibration plot was $58.0 \pm 0.5$ $\mathrm{mV} \cdot \mathrm{decade}^{-1}$. The calibration plot is shown in Figure 2, which indicates that the modified sensor shows a linear range from $1 \times 10^{-6}$ to $1 \times 10^{-1} \mathrm{~mol} \cdot \mathrm{L}^{-1}$. The practical limit of detection, defined as the concentration of cesium ion obtained from the intersection of two extrapolated segments of the calibration graph, was about $3 \times 10^{-7}$ $\mathrm{mol} \cdot \mathrm{L}^{-1}$. The optimum equilibration times for cesium

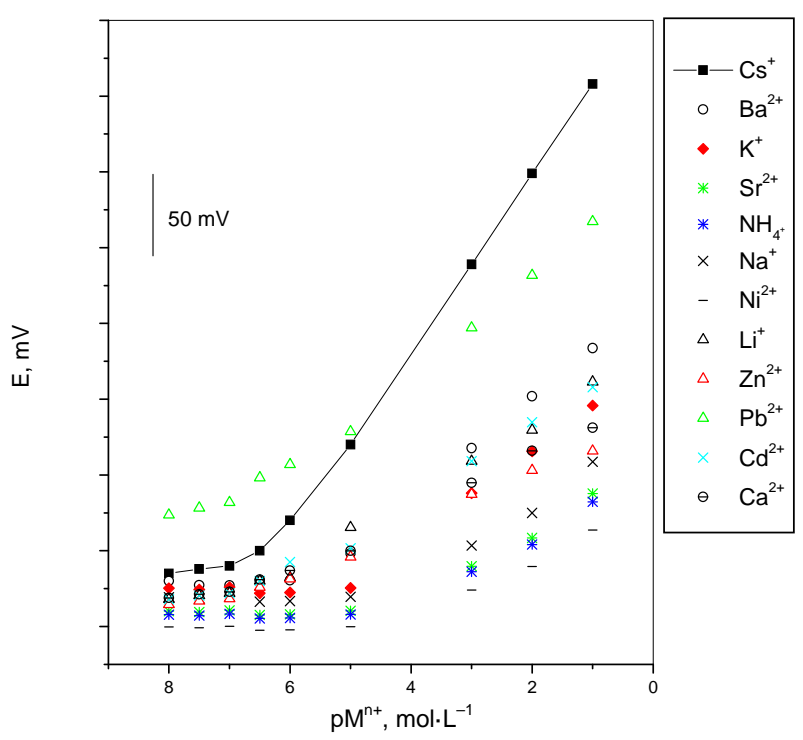

Figure 1. Calibration graphs of some inorganic cations using CMCP electrode. 


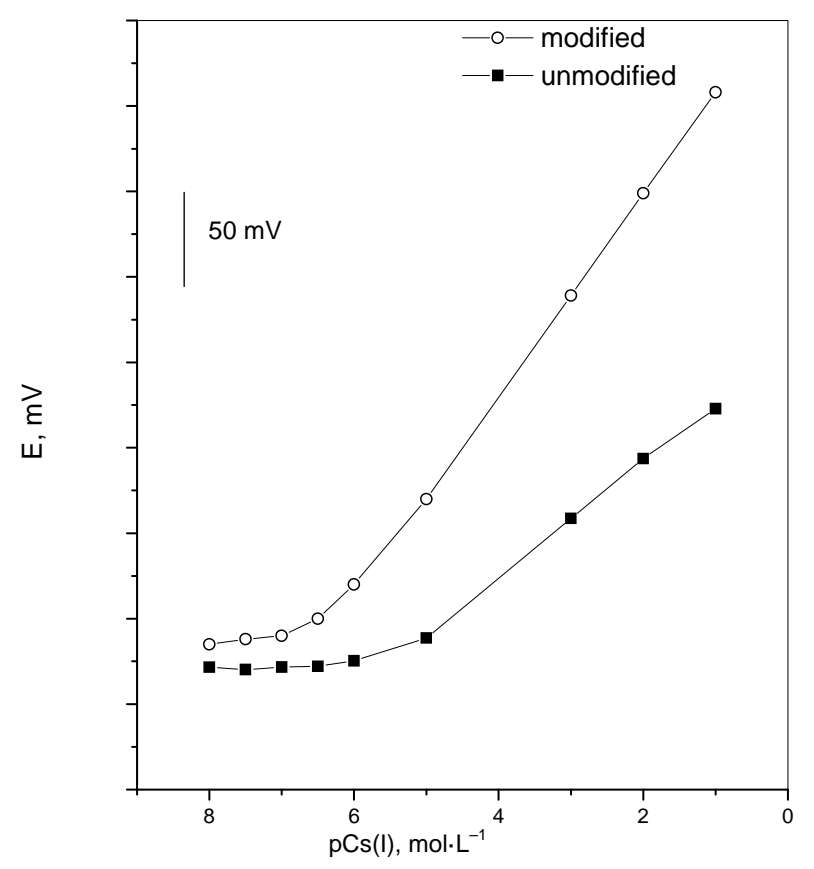

Figure 2. Potentiometric calibration response of Cs-potassium zinc ferrocyanide based Cesium electrode.

selective electrode in the presence of $10^{-4} \mathrm{~mol} \cdot \mathrm{L}^{-1}$ cesium ion was $1 \mathrm{~h}$, after which the electrode would generate stable potentials in contact with Cs(I) solutions. The characteristic properties of the optimized paste are summarized in Table 1. The stability and reproducibility of the electrodes were also tested. The standard deviation of 10 replicate measurements at $10^{-3} \mathrm{~mol} \cdot \mathrm{L}^{-1} \mathrm{Cs}(\mathrm{I})$ was \pm 0.9 $\mathrm{mV}$. The long term stability of the electrode was studied by periodically recalibrating in standard solutions and calculating the response slope over the range of $10^{-6}-10^{-1}$ $\mathrm{mol} \cdot \mathrm{L}^{-1}$. The detection electrode was very stable and could be used over a period of at least 3 months. The slopes of the electrode response decreased from 58 to 50 $\mathrm{mV} \cdot \mathrm{decade}^{-1}$ over a period of 3 months. The data obtained is summarized in Table 2.

\subsection{Effect of Plasticizer Type}

Besides the critical role of the nature and the amount of PZHCF ionophore on the characteristics of the sensors, some other important features such as the nature of the solvent mediator, the plasticizer/PVC ratio and the nature of any additives used, are known to significantly influence the sensitivity and selectivity of ion-selective electrodes.

The nature of the plasticizer influences both dielectric constant of the membrane and the mobility of the ionophore.

The solvent mediator has a dual function, it acts as liquefying agent, enabling homogeneous solubilization and modifying the distribution constant of the PZHCF
Table 2. Potentiometric response characteristics of the modified carbon paste electrode.

\begin{tabular}{lc}
\hline Parameter & Value \\
\hline Slope, $\left(\mathrm{mV} \cdot\right.$ decade $\left.^{-1}\right)$ & $58.0 \pm 0.5$ \\
Linear range, $\mathrm{mol} \cdot \mathrm{L}^{-1}$ & $1 \times 10^{-6}-1 \times 10^{-1}$ \\
Lower limit of Linear range, $\mathrm{mol} \cdot \mathrm{L}^{-1}$ & $1 \times 10^{-6}$ \\
Lower limit of detection, $\mathrm{mol} \cdot \mathrm{L}^{-1}$ & $3 \times 10^{-7}$ \\
Lower limit of quantification, $\mathrm{mol} \cdot \mathrm{L}^{-1}$ & $9.99 \times 10^{-7}$ \\
Response time, $\mathrm{s}$ & $<35$ \\
Working pH range & $4-8$ \\
$\quad$ Life time, month & 3 \\
$\quad$ Percent recovery & $96.85-98.20$ \\
Standard deviation & $0.035-0.052$ \\
Relative standard deviation $(\%)$ & $0.86-1.29$ \\
\hline
\end{tabular}

ionophore used. For plasticizer to be adequate for use in sensors, it should gather certain properties and characteristics, such as having high lipophilicity, high molecular weight, low vapor pressure, and high capacity to dissolve the substrate and other additives present in the matrix [31]. The influence of the plasticizer type and its quantity on the characteristics of the studied sensors was investigated using five plasticizers with different polarities including DBP, DOP, DOS, TCP and $o$-NPOE. As shown in Figure 3, the electrode containing TCP generally shows better potentiometric responses, i.e. sensitivity and linearity range of the calibration plots. This is due to its high dielectric constant and relatively high molecular weight.

\subsection{Effect of $\mathbf{p H}$}

The effect of $\mathrm{pH}$ on the response of the modified Cs carbon paste electrode was examined at $1 \times 10^{-2}$ and $1 \times 10^{-3}$ $\mathrm{mol} \cdot \mathrm{L}^{-1}$ concentrations of $\mathrm{Cs}(\mathrm{I})$. The $\mathrm{pH}$ was adjusted with dilute nitric acid and sodium hydroxide as required. As illustrated in Figure 4, the potentials remained constant within the $\mathrm{pH}$ range of approximately $4-8$; the potential did not vary by more than $\pm 1 \mathrm{mV}$. The significant effect of $\mathrm{pH}$ on the electrode potential at $\mathrm{pH}<4$ and $\mathrm{pH}$ $>8$ is attributed to the competition of $\mathrm{H}^{+}$ions at low $\mathrm{pH}$ and to instability of the exchanger based carbon paste at high $\mathrm{pH}$, respectively.

\subsection{Response Time}

For analytical applications, the response time of an electrode is of critical importance. The response time is defined as the time elapsed from the dropping of the electrode in the solution until the equilibrium potential was reached. Also the average time required for the electrode to reach a steady potential response within $\pm 1 \mathrm{mV}$ of the final equilibrium value. After successive immersion of a 


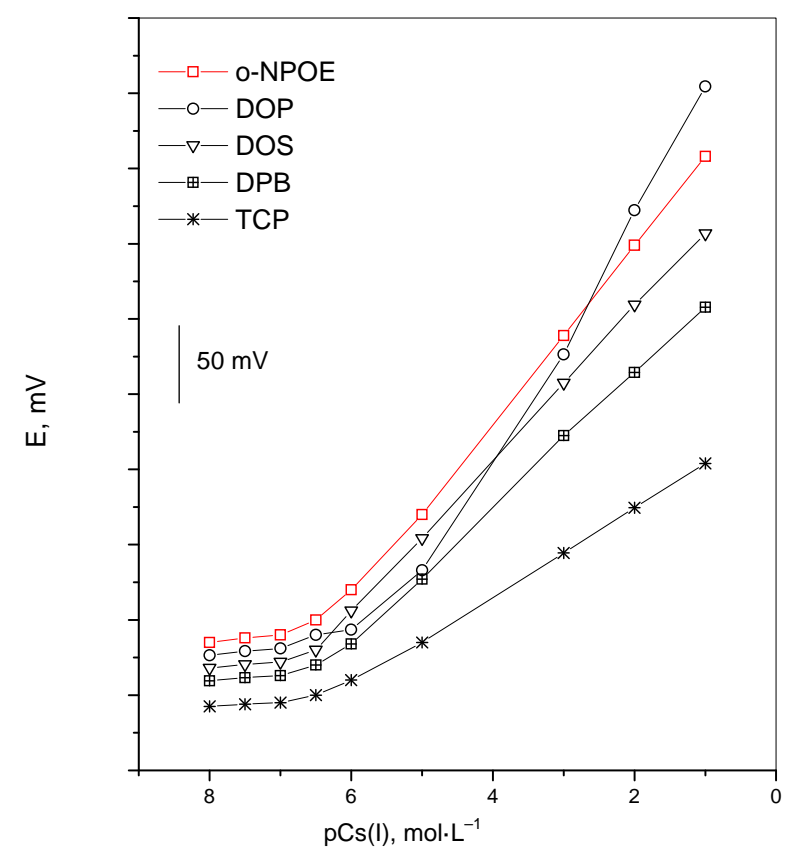

Figure 3. Effect of plasticizer on potential response of CMCP electrode.

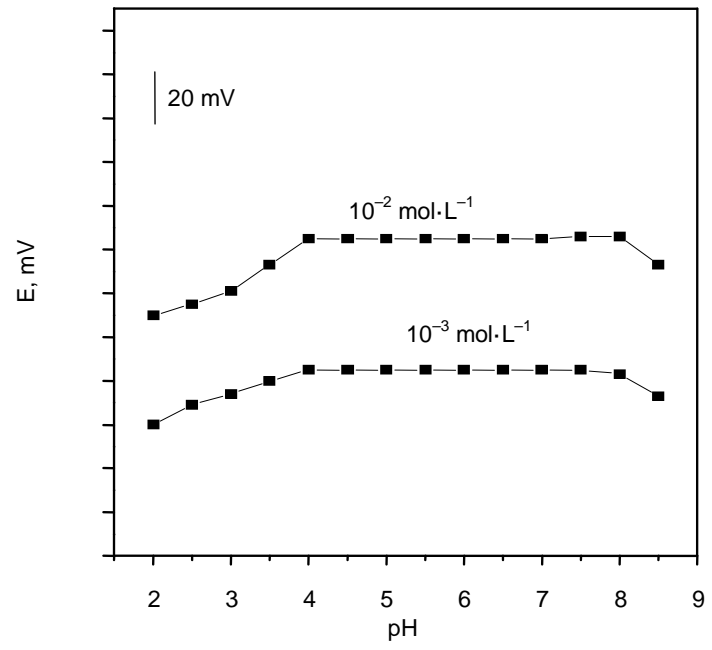

Figure 4. Effect of $\mathrm{pH}$ on the potentiometric response of Cs-potassium zinc ferrocyanide based Cesium electrode.

series of $\mathrm{Cs}(\mathrm{I})$ solutions, each having a tenfold difference in concentration was investigated. Response time inherent to ion selective electrodes are only measurable if the overall response time of the potentiometric system is governed by the properties of the paste of electrode, i.e. if the time constant of the response function of the electrode is much larger than the time constant of the electrochemical cell and the electronic EMF-measuring device. Indeed, the overall response time is affected by a series of factors, for example the constant of the measuring instrument, the impedance of the equivalent electric circuit of the paste, the rate of the ion transfer reaction across the paste- sample interface, the establishment of a liquid-junction potential at the reference electrode [32]. The result clearly indicate that, Figure 5, all the potentiometric response times of the electrode in the concentration range of $1 \times 10^{-6}-1 \times 10^{-1} \mathrm{~mol} \cdot \mathrm{L}^{-1} \mathrm{Cs}(\mathrm{I})$ were less than $1 \mathrm{~min}$. However, in most cases the resulting potential time response was obtained upon changing the target ion concentration from $1 \times 10^{-3}$ to $1 \times 10^{-2} \mathrm{~mol} \cdot \mathrm{L}^{-1}$. Thus, we concluded that the potentiometric response time of the electrode was a bout $35 \mathrm{sec}$.

\subsection{Electrode Selectivity}

The selectivity behaviour is one of the most important characteristics of an ion-selective electrode, which is the relative electrode response to a specific ion (A) over other ions present in solution (B). This is measured in terms of potentiometric selectivity coefficients $\left(\mathrm{K}^{\mathrm{pot}}{ }_{\mathrm{A}, \mathrm{B}}\right)$. In this work, the separate solution method (SSM) [33] was used to determine selectivity coefficients of the proposed electrode. It is calculated as:

$$
\log \mathrm{K}_{\mathrm{A}, \mathrm{B}}^{\mathrm{pot}}=\left[\left(\mathrm{E}_{\mathrm{B}}-\mathrm{E}_{\mathrm{A}}\right) / \mathrm{S}\right]+\left(1-\left(\mathrm{Z}_{\mathrm{B}} / \mathrm{Z}_{\mathrm{A}}\right)\right) \log \mathrm{a}_{\mathrm{A}}
$$

$E_{A}$ and $E_{B}$ mean the potentiometric response of $a_{A}$ and $a_{B}$, respectively. $a_{A}$ is the primary ion activity and $a_{B}$ is the activity of an interfering ion. The single ion activities were calculated by the extended Debye-Hückel equation [34]. In this work, $\mathrm{a}_{\mathrm{A}}\left(1.0 \times 10^{-3} \mathrm{~mol} \cdot \mathrm{L}^{-1} \mathrm{Cs}(\mathrm{I})\right.$ ion $)$ and $\mathrm{a}_{\mathrm{B}}\left(1.0 \times 10^{-3} \mathrm{~mol} \cdot \mathrm{L}^{-1}\right.$ interfering ion $)$ were used to measure the selectivity coefficients. S, Nernstian slope, $Z_{\mathrm{A}}$ and $Z_{\mathrm{B}}$ are the charge of the primary and interfering ions, respectively.

Also, matched potential method (MPM) was used to measure the selectivity coefficient. According to this

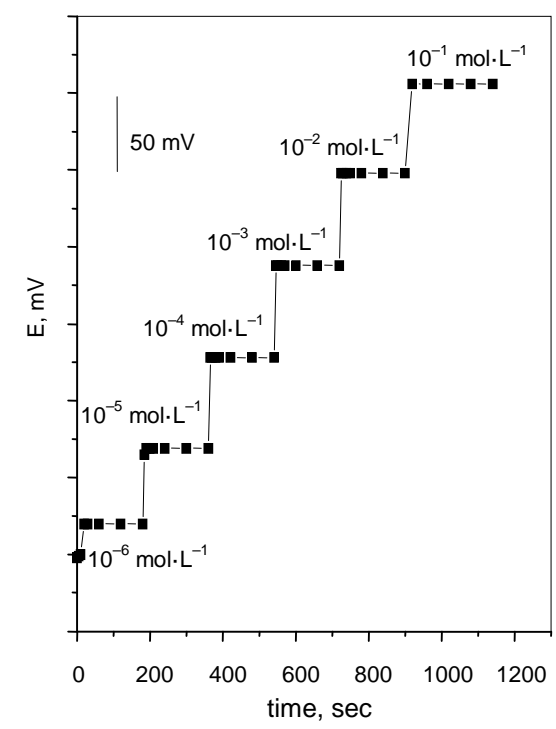

Figure 5. Potential-time plot for the response of CMCP electrode. 
method, the activity of $\mathrm{Cs}(\mathrm{I})$ was increased from $\mathrm{a}_{\mathrm{A}}=$ $1.0 \times 10^{-5} \mathrm{~mol} \cdot \mathrm{L}^{-1}$ (reference solution) to $\mathrm{a}_{\mathrm{A}}^{\prime}=1.0 \times$ $10^{-3} \mathrm{~mol} \cdot \mathrm{L}^{-1}$, and the change in potential $(\Delta \mathrm{E})$ corresponding to this increase in activity is measured. Then, $0.1 \mathrm{~mol} \cdot \mathrm{L}^{-1}$ solution of an interfering ion is added to a new $1.0 \times 10^{-5} \mathrm{~mol} \cdot \mathrm{L}^{-1} \mathrm{Cs}(\mathrm{I})$ reference solution until the same potential change $(\Delta \mathrm{E})$ is recorded, the concentration of the added amount is thus $\mathrm{a}_{\mathrm{B}}$. The selectivity coefficient $\mathrm{K}_{\mathrm{A}, \mathrm{B}}^{\mathrm{MPM}}$ for each interferent was calculated using the following equation:

$$
\mathrm{K}_{\mathrm{A}, \mathrm{B}}^{\mathrm{pot}}=\left(\mathrm{a}_{\mathrm{A}}^{\prime}-\mathrm{a}_{\mathrm{A}}\right) / \mathrm{a}_{\mathrm{B}}
$$

Possible interferences from a number of cations were studied and the results are shown in Table 3. It is obvious from Table 3 that most of the selectivity coefficients are very low, indicating no significant interference in the performance of the electrode performance for determining the $\mathrm{Cs}(\mathrm{I})$ ion.

Table 3. Potentiometric selectivity coefficient values of Cs-ZHCF carbon paste electrode.

\begin{tabular}{|c|c|c|}
\hline \multirow{2}{*}{ Interfering Species } & \multicolumn{2}{|c|}{$\log \mathrm{K}_{\mathrm{CS}^{+}, \mathrm{B}}^{\mathrm{pot}}$} \\
\hline & SSM & MPM \\
\hline $\mathrm{Na}$ & -2.5 & -2.32 \\
\hline $\mathrm{Ca}$ & -6.9 & -6.75 \\
\hline K & -2.43 & -2.22 \\
\hline $\mathrm{Cd}$ & -6.68 & -6.84 \\
\hline $\mathrm{Ni}$ & -4.53 & -4.67 \\
\hline Co & -4.70 & -4.62 \\
\hline $\mathrm{Al}$ & -7.46 & -7.29 \\
\hline $\mathrm{Hg}$ & -7.94 & -8.00 \\
\hline $\mathrm{Pb}$ & -6.29 & -6.05 \\
\hline $\mathrm{Zn}$ & -5.48 & -5.65 \\
\hline $\mathrm{Li}$ & -2.90 & -3.12 \\
\hline $\mathrm{Rb}$ & -2.60 & -2.43 \\
\hline $\mathrm{NH}_{4}$ & -2.49 & -2.55 \\
\hline $\mathrm{Ba}$ & -1.90 & -2.11 \\
\hline $\mathrm{Sr}$ & -1.98 & -2.09 \\
\hline $\mathrm{Mn}$ & -2.40 & -2.49 \\
\hline U & -2.41 & -2.48 \\
\hline $\mathrm{La}$ & -2.42 & -2.46 \\
\hline $\operatorname{Pr}$ & -3.43 & -3.40 \\
\hline $\mathrm{Nd}$ & -2.44 & -2.49 \\
\hline $\mathrm{Sm}$ & -2.49 & -3.40 \\
\hline Y & -3.40 & -2.48 \\
\hline $\mathrm{Zr}$ & -3.40 & -2.41 \\
\hline Mo & -2.46 & -2.90 \\
\hline $\mathrm{Ce}$ & -2.44 & -2.99 \\
\hline
\end{tabular}

\subsection{Effect of Temperature}

To investigate the thermal stability of the modified electrode, calibration graphs $\left[\mathrm{E}_{\text {cell }}\right.$ versus $\left.\mathrm{p}[\mathrm{Cs}]\right]$ were constructed at different test solution temperature covering the range $25^{\circ} \mathrm{C}-55^{\circ} \mathrm{C}$. The electrode exhibits good Nernstian behaviour in the temperature range. The standard cell potentials $\left(\mathrm{E}_{\text {cell }}^{\circ}\right)$, were determined at different temperatures from the respective calibration plots as the intercepts of these plots at $\mathrm{P}^{\mathrm{Cs}}=0$, and were used to determine the thermal temperature coefficient $\left(\mathrm{dE}^{\circ} / \mathrm{dt}\right)$ of the cell with the aid of the following equation [35],

$$
\mathrm{E}_{\text {cell }}^{\circ}=\mathrm{E}_{\text {cell }}^{\circ}\left(25^{\circ} \mathrm{C}\right)+\left[\left(\mathrm{dE}^{\circ}\right)_{\text {cell }} / \mathrm{dt}\right](\mathrm{t}-25)
$$

Plot of $\mathrm{E}_{\text {cell }}^{\mathrm{o}}$ versus ( $\left.\mathrm{t}-25\right)$ produced a straight line of slope equals to $3.1 \times 10^{-4} \mathrm{~V} /{ }^{\circ} \mathrm{C}$, Figure 6. This value is the thermal temperature coefficient of the cell. The values of the standard potentials of Cs-CMCP electrode were calculated at different temperatures from the relation:

$$
\mathrm{E}_{\text {electrode }}^{\circ}=\mathrm{E}_{\text {cell }}^{\circ}+\mathrm{E}_{\text {reference }}^{\circ}
$$

Plot of $E_{\text {electrode }}^{\circ}$ versus $(t-25)$ gave a straight line; its slope was taken as the thermal temperature coefficient of the electrode which amounts to $0.5 \times 10^{-5} \mathrm{~V} /{ }^{\circ} \mathrm{C}$. The small values of $\left(\mathrm{dE}^{\circ} / \mathrm{dt}\right)_{\text {cell }}$ and $\left(\mathrm{dE}^{\circ} / \mathrm{dt}_{\text {electrode }}\right.$ reveal the high thermal stability of the electrode within the investigated temperature range.

\subsection{Determination of Cesium Ion in Some Water Samples}

Cesium determination was made in three different sam-

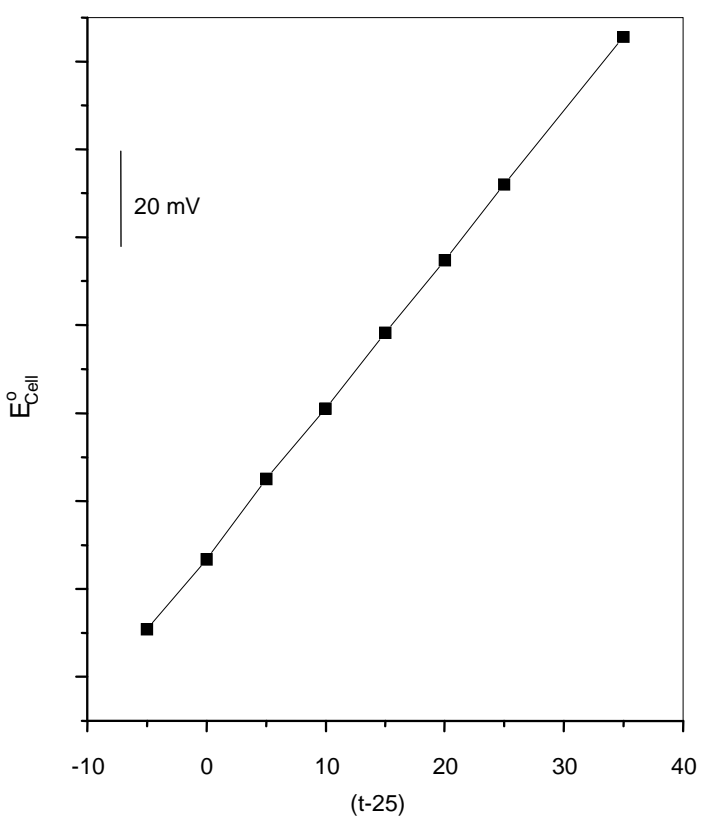

Figure 6. Variation of the cell emf with the temperature for the CPCP electrode. 
ples, Nile River, rainwater and tap water. Same samples were analyzed with atomic absorption and results were compared. The aim of the sample study is to test the accuracy of the results achieved by the analyses done with the cesium electrode. Therefore, simple treatments were chosen to prepare the samples. The Nile river sample was collected in a $500 \mathrm{~mL}$ polyethylene container that was previously soaked in 10\% sulfuric acid for one hour and subsequently rinsed with bidistilled water. The rainwater sample was collected in a glass container that had been treated with $1 \mathrm{M}$ nitric acid and washed with bidistilled water. Prior to analysis, natural water samples were filtered to eliminate visible impurities, while the tap water sample was used without filtering. The $\mathrm{pH}$ was adjusted by nitric acid and sodium hydroxide. Standard additions of cesium ion solutions were made and cesium ion quantities were calculated by using:

$$
\mathrm{C}_{\mathrm{x}}=\mathrm{C}_{\mathrm{s}} \mathrm{V}_{\mathrm{s}} /\left(\mathrm{V}_{\mathrm{x}}+\mathrm{V}_{\mathrm{s}}\right) 10^{\Delta \mathrm{E} / \mathrm{s}}-\mathrm{V}_{\mathrm{x}}
$$

where $\mathrm{C}_{\mathrm{s}}$ concentration of the standard which is added, $\mathrm{C}_{\mathrm{x}}$ concentration of the sample, $\mathrm{V}_{\mathrm{x}}$ volume of the sample, $\mathrm{Vs}$ volume of the standard which is added, $\Delta \mathrm{E}$ change in the cell potential, $\mathrm{S}$ slope of the electrode against $\mathrm{X}$ ion. An aliquot (unknown to the analyst) of $1 \times 10^{-5} \mathrm{~mol} \cdot \mathrm{L}^{-1}$ Cs(I) standard was added to the sample and the cesium concentrations were determined. Table 4 summarizes the results obtained for all of the water samples. The results show a good correlation with the data obtained by atomic absorption spectrometric method.

\subsection{Determination of Cs in Simulated High Level Active Waste}

The proposed CMCP electrode was calibrated using the solutions in the beakers numbers from 5 to 8 and employing the procedures 1 and 2 given in the experimental section. The procedures 1 and 2 gave the calibration slope as $55.6 \pm 0.4$ and $56.2 \pm 0.3 \mathrm{mV} \cdot$ decade $^{-1}$, respectively. The response of the CMCP electrode to Cs ions was then measured using the solutions in beakers numbers from 1 to 4 . Using procedure 3, the CMCP electrode was calibrated from the potential response in beakers 3,4 , 7 and 8 before and after dilution. The calibration slope was found to be $55.6 \pm 0.5 \mathrm{mV} \cdot$ decade $^{-1}$. From the calibration data and potential responses in beakers $1,2,5$ and 6 , the $\mathrm{Cs}(\mathrm{I})$ concentration was determined in the simulated waste solutions (SIM 1 and SIM 2). In all the three procedures, only the Cs ions concentration was considered for calibration. Due to the high ionic strength of the solutions (presence of large amount of salts), activity of $\mathrm{Cs}(\mathrm{I})$ got reduced, and hence the slope of calibration deviated more from the Nernstian response. Results for all the three procedures are given in Table 5. The present method was validated with AAS. Our CMCP electrode results agreed well with the AAS values (Table 5).

\section{Method Validation}

\subsection{Linearity and Range}

The calibration graphs obtained by plotting the potential values versus the final concentration were found to be rectilinear over the concentration range cited in Figure 1.

\subsection{Limit of quantification and Limit of Detection}

The limit of quantification (LOQ) was determined by establishing the least concentration that can be measured

Table 4. Determination of cesium(I) in different water samples using the proposed electrode.

\begin{tabular}{|c|c|c|c|c|c|c|c|}
\hline \multirow[b]{2}{*}{ Sample } & \multirow{2}{*}{$\begin{array}{l}{[\mathrm{Cs}(\mathrm{I})]} \\
\text { Added, } \\
\mathrm{mol} \cdot \mathrm{L}^{-1}\end{array}$} & \multicolumn{2}{|c|}{$[\mathrm{Cs}(\mathrm{I})]$ Found, $\mathrm{mol} \cdot \mathrm{L}^{-1}$} & \multicolumn{2}{|c|}{$\mathrm{RSD}, \%$} & \multicolumn{2}{|c|}{ Recovery, \% } \\
\hline & & MCPE method* & AAS** method & $\begin{array}{l}\text { MCPE } \\
\text { method* }\end{array}$ & $\begin{array}{l}\text { AAS** } \\
\text { method }\end{array}$ & $\begin{array}{l}\text { MCPE } \\
\text { method* }\end{array}$ & $\begin{array}{l}\text { AAS** } \\
\text { method }\end{array}$ \\
\hline Nile river & $1.0 \times 10^{-5}$ & $9.50 \times 10^{-6}$ & $9.90 \times 10^{-6}$ & 0.32 & 0.42 & 95.00 & 99.00 \\
\hline Rain water & $1.0 \times 10^{-5}$ & $9.60 \times 10^{-6}$ & $9.80 \times 10^{-5}$ & 0.67 & 0.62 & 96.00 & 98.00 \\
\hline Tap water & $1.0 \times 10^{-5}$ & $9.89 \times 10^{-6}$ & $9.93 \times 10^{-6}$ & 0.35 & 0.52 & 98.90 & 99.30 \\
\hline
\end{tabular}

*Developed method; **Standard method.

Table 5. Determination of cesium in simulated high level active waste solution and comparison with AAS.

\begin{tabular}{|c|c|c|c|c|c|c|c|c|c|}
\hline \multirow[t]{3}{*}{$\begin{array}{l}\text { Sample } \\
\text { ID }\end{array}$} & \multirow[t]{3}{*}{$\begin{array}{l}{[\mathrm{Cs}(\mathrm{I})] \text { Taken }} \\
\left(\mathrm{mg} \cdot \mathrm{L}^{-1}\right)\end{array}$} & \multicolumn{4}{|c|}{$[\mathrm{Cs}(\mathrm{I})]$ Found $\left(\mathrm{mg} \cdot \mathrm{L}^{-1}\right)$} & \multicolumn{4}{|c|}{ Percentage recovery $\pm \mathrm{RSD}(\%)$} \\
\hline & & \multicolumn{3}{|c|}{ MCPE method* } & \multirow[t]{2}{*}{$\begin{array}{l}\text { AAS** } \\
\text { method }\end{array}$} & \multicolumn{3}{|c|}{ MCPE method* } & $\begin{array}{l}\mathrm{AAS}^{* *} \\
\text { method }\end{array}$ \\
\hline & & Method 1 & Method 2 & Method 3 & & Method 1 & Method 2 & Method 3 & \\
\hline SIM 1 & 0.090 & 0.088 & 0.087 & 0.090 & 0.087 & $97.78 \pm 2.05$ & $96.67 \pm 1.99$ & $100.0 \pm 2.36$ & $96.67 \pm 1.76$ \\
\hline SIM 2 & 0.220 & 0.223 & 0.212 & 0.222 & 0.218 & $101.4 \pm 1.68$ & $96.36 \pm 2.43$ & $100.9 \pm 1.85$ & $99.09 \pm 2.01$ \\
\hline
\end{tabular}

*Mean of five determinations; **Mean of two determinations. 
according to ICH Q2(R1) recommendations, below which the calibration range is non linear. It was found to be $1 \times 10^{-6} \mathrm{~mol} \cdot \mathrm{L}^{-1}$. The limit of detection (LOD) was determined by evaluating the lowest concentration of the $\mathrm{Cs}(\mathrm{I})$ ion analyte that can be readily detected and was found to be $3 \times 10^{-7} \mathrm{~mol} \cdot \mathrm{L}^{-1}$. The LOQ and LOD were calculated according to the following equations (ICH 2005):

$$
\begin{aligned}
& \mathrm{LOQ}=10 \mathrm{~S}_{\mathrm{a}} / \mathrm{b} \\
& \mathrm{LOD}=3.3 \mathrm{~S}_{\mathrm{a}} / \mathrm{b}
\end{aligned}
$$

where $\left(\mathrm{S}_{\mathrm{a}}\right)$ is the standard deviation of the intercept of the regression line and (b) is the slope of the calibration curve.

\subsection{Specificity}

The specificity of the method was investigated by observing any interference encountered from the common inorganic cations (Table 3). It was found that these cations did not interfere with the results of the proposed method as shown in Table 3.

\subsection{Accuracy and Precision}

To prove the accuracy of the proposed method, the results of the assay of the studied $\mathrm{Cs}(\mathrm{I})$ in different real samples were compared with the atomic absorption method, the statistical analysis of the results using percent recovery and relative standard deviation values showed no significant differences between them regarding accuracy and precision, Tables 4, 5. Intra- and interday precisions were assessed using three concentrations and four replicates of each concentration, the relative standard deviations were found to be very small indicat- ing reasonable repeatability of the proposed method as shown in Table 6.

\subsection{Ruggedness and Robustness}

The ruggedness of the proposed method was assessed by applying the procedures using two different instruments in two different laboratories at different elapsed time. Results obtained from lab-to-lab and day-to-day variations were found to be reproducible as RSD did not exceed $2 \%$. While robustness was assessed by evaluating the influence of small concentration variation of $\mathrm{Cs}(\mathrm{I})$ and $\mathrm{pH}$. The small variations in any of the variables did not significantly affect the results. The mean recoveries were found to be $97.77 \% \pm 0.887 \%-99.32 \% \pm 0.657 \%$.

\section{Comparison with Other Electrodes}

A comparative study of the response characteristics of the proposed electrode with the reported Cs(I) ion selective electrodes based on other carriers is shown in Table 7. The results indicate that the proposed electrode is superior to the previous reported $\mathrm{Cs}(\mathrm{I})$ ion selective electrodes with regard to the linear range, detection limit, slope and selectivity over a number of cations.

\section{Conclusion}

A novel electrochemical sensor incorporating potassium zinc hexacyanoferrate as a sensing material and o-NPOE as solvent mediator in carbon paste matrix could be used to determine $\mathrm{Cs}(\mathrm{I})$ ion in the concentration range $1.0 \times$ $10^{-6}-1.0 \times 10^{-1} \mathrm{~mol} \cdot \mathrm{L}^{-1}$ with a slope of $58 \pm 0.5$ $\mathrm{mV} \cdot \mathrm{decade}^{-1}$. This electrode is very easy to prepare, show high selectivity and sensitivity, wide dynamic range,

\begin{tabular}{|c|c|c|c|c|c|c|c|c|c|}
\hline & \multirow{2}{*}{$\begin{array}{l}\text { Taken, } \\
\mathrm{mg} \cdot \mathrm{mL}^{-1}\end{array}$} & \multicolumn{4}{|c|}{ Intra day } & \multicolumn{4}{|c|}{ Inter day } \\
\hline & & $\begin{array}{l}\text { Found, } \\
\mathrm{mg} \cdot \mathrm{mL}^{-1}\end{array}$ & $\begin{array}{c}\text { Recovery } \\
\%\end{array}$ & $\mathrm{SD}^{*}$ & $\begin{array}{c}\text { RSD } \\
\%\end{array}$ & $\begin{array}{l}\text { Found, } \\
\mathrm{mg} \cdot \mathrm{mL}^{-1}\end{array}$ & $\begin{array}{c}\text { Recovery } \\
\%\end{array}$ & $\mathrm{SD}$ & $\begin{array}{c}\text { RSD } \\
\%\end{array}$ \\
\hline \multirow[t]{2}{*}{ Pure } & 0.118 & 0.1168 & 98.96 & 0.007 & 1.75 & 0.1186 & 100.5 & 0.004 & 0.99 \\
\hline & 0.240 & 0.2395 & 99.81 & 0.012 & 2.29 & 0.2391 & 99.63 & 0.008 & 1.51 \\
\hline \multirow[t]{2}{*}{ Nile river } & 0.118 & 0.1177 & 99.74 & 0.008 & 2.15 & 0.1189 & 100.8 & 0.008 & 2.05 \\
\hline & 0.240 & 0.2391 & 99.63 & 0.012 & 2.24 & 0.2405 & 100.2 & 0.012 & 2.26 \\
\hline \multirow{3}{*}{ Rain water } & 0.050 & 0.0498 & 99.60 & 0.004 & 1.44 & 0.0490 & 98.00 & 0.004 & 1.48 \\
\hline & 0.118 & 0.1177 & 99.74 & 0.010 & 2.56 & 0.1171 & 99.22 & 0.008 & 2.10 \\
\hline & 0.240 & 0.2409 & 100.4 & 0.015 & 2.85 & 0.2387 & 99.44 & 0.014 & 2.65 \\
\hline \multirow{3}{*}{ Tap water } & 0.050 & 0.0492 & 98.40 & 0.003 & 1.39 & 0.0488 & 97.60 & 0.005 & 1.87 \\
\hline & 0.118 & 0.1165 & 98.70 & 0.008 & 2.05 & 0.1171 & 99.22 & 0.008 & 2.09 \\
\hline & 0.240 & 0.2405 & 100.2 & 0.011 & 1.98 & 0.2382 & 99.26 & 0.010 & 1.87 \\
\hline
\end{tabular}

Table 6. Intra- and Inter-days precision of the determination of Cs(I) in pure and water samples using the modified CPE. 
Table 7. Comparative studies of cesium carbon paste ion selective electrode based on potassium zinc hexacyanoferrate ionophore and the previously described ionophores.

\begin{tabular}{|c|c|c|c|c|c|c|c|c|}
\hline \multirow{2}{*}{ Ionophore } & \multirow{2}{*}{$\begin{array}{l}\text { Linearity, } \\
\mathrm{mol} \cdot \mathrm{L}^{-1}\end{array}$} & \multirow{2}{*}{$\begin{array}{l}\mathrm{LOD}^{*} \\
\mathrm{~mol} \cdot \mathrm{L}^{-1}\end{array}$} & \multirow{2}{*}{$\begin{array}{c}\text { Slope, } \\
\mathrm{mV} \cdot \text { decade }^{-1}\end{array}$} & \multicolumn{5}{|c|}{ Selectivity } \\
\hline & & & & $\mathrm{Li}^{+}$ & $\mathrm{Na}^{+}$ & $\mathrm{K}^{+}$ & $\mathrm{Rb}^{+}$ & $\mathrm{NH}_{4}^{+}$ \\
\hline $\begin{array}{l}\text { 15-Crown-5-phoshotungestic } \\
\text { acid reciitate [36] }\end{array}$ & $0.1-1.0 \times 10^{-4}$ & $1.0 \times 10^{-5}$ & 60 & -0.89 & -0.46 & -0.31 & -0.46 & - \\
\hline $\begin{array}{l}\text { 2,3- Benzoquino-15- } \\
\text { Crown-5 [37] }\end{array}$ & $0.1-1.0 \times 10^{-4}$ & $1.0 \times 10^{-5}$ & 51.9 & -3.00 & -2.38 & -0.99 & -0.47 & -1.40 \\
\hline $\begin{array}{l}\text { p-Methoxy-anilino } \\
\text { (1,3-dioxo-2-indenylidene) } \\
\text { acetonitrile [38] }\end{array}$ & $0.1-2.5 \times 10^{-5}$ & $6.3 \times 10^{-6}$ & 52 & -3.33 & -2.72 & -1.22 & -0.70 & -1.59 \\
\hline 14,15-Crown- formazans[39] & $0.1-5.0 \times 10^{-4}$ & $2.0 \times 10^{-4}$ & $47-50$ & -2.5 & -2.85 & -1.46 & - & -1.39 \\
\hline Calix $\{4\}$ arene dibenzo-crown-6 [40] & $0.1-1.0 \times 10^{-6}$ & $<10^{-6}$ & 58.7 & -4.80 & -4.90 & -2.30 & -0.8 & -1.90 \\
\hline Calix $\{6\}$ arene tetraester $[40]$ & $0.1-1.0 \times 10^{-6}$ & $<10^{-6}$ & 55.7 & -5.12 & -3.25 & -2.23 & -1.88 & -3.01 \\
\hline $\begin{array}{l}\text { calix[4]arene-crown-6 } \\
\text { compounds [41] }\end{array}$ & $0.01-1 \times 10^{-6}$ & $8.4 \times 10^{-8}$ & 56.6 & -5.2 & -4.68 & 2.37 & -1.22 & -2.14 \\
\hline $\begin{array}{l}\text { 1,3-alternate thiacalix }\{4\} \\
\text { biscrown-6,6 [29] }\end{array}$ & $\begin{array}{c}3.2 \times 10^{-2} \\
-1.0 \times 10^{-6}\end{array}$ & $3.8 \times 10^{-7}$ & 57.6 & -4.1 & -4.3 & -3.7 & -1.4 & -2.5 \\
\hline $\begin{array}{l}\text { Crown bridged thiacalix } \\
\{4\} \text { arenes }[27]\end{array}$ & $0.1-9.0 \times 10^{-8}$ & $<10^{-7}$ & 58.0 & - & -5.10 & -3.50 & -2.20 & -3.10 \\
\hline $\begin{array}{l}\text { Diisopropyl dihydroxy } \\
\text { Calix }\{4\} \text { mono azo para } \\
\text { nitrophenyl aniline }[24]\end{array}$ & $0.1-1.0 \times 10^{-5}$ & $4.6 \times 10^{-6}$ & 56.0 & - & -3.13 & -2.27 & -0.85 & -1.58 \\
\hline $\begin{array}{l}\text { Potassiun zinc hexacyanoferrate } \\
\text { [this work] }\end{array}$ & $0.1-1.0 \times 10^{-6}$ & $<10^{-6}$ & 58 & -2.90 & -2.50 & -2.43 & -2.60 & -2.49 \\
\hline
\end{tabular}

and low detection limit. The working $\mathrm{pH}$ range of this electrode is $4-6$. The response time for the static potential was found to be significantly low, hence the electrode can be also applied for cesium ion estimation in dynamic conditions. The results agreed with those given by an atomic absorption spectrometric method.

\section{Acknowledgements}

We thank Prof. Dr. Mahmoud S. Rizk for his help and revising the manuscript.

\section{REFERENCES}

[1] K. Kalcher, J. M. Kauffmann, J. Wang, I. Svancara, K. Vytras, C. Neuhold and Z. Yang, "Sensors Based on Carbon Paste in Electrochemical Analysis: A Review with Particular Emphasis on the Period 1990-1993," Electroanalysis, Vol. 7, No. 1, 1995, pp. 5-22. doi:10.1002/elan.1140070103

[2] J. Wang, "Electroanalytical Chemistry," 2nd Edition. Wiley, New York, 2000.

[3] M. N. Abbas, "Chemically Modified Carbon Paste Electrode for Iodide Determination on the Basis of Cetyltrimethylammonium Iodide Ion-Pair," Analytical Sciences, Vol. 19, No. 2, 2003, pp. 229-233. doi:10.2116/analsci.19.229

[4] M. K. Amini, J. H. Khorasani, S. S. Khaloo and S. Tangestaninejad, "Cobalt(II) Salophen-Modified CarbonPaste Electrode for Potentiometric and Voltammetric De- termination of Cysteine," Analytical Biochemistry, Vol. 320, No. 1, 2003, pp. 32-38. doi:10.1016/S0003-2697(03)00355-5

[5] M. J. Gismera, M. A. Mendiola, J. R. Procopio and M. T. Sevilla, "Copper Potentiometric Sensors Based on Copper Complexes Containing Thiohydrazone and Thiosemicarbazone Ligands," Analytica Chimica Acta, Vol. 385, No. 1-3, 1999, pp. 143-149. doi:10.1016/S0003-2670(98)00840-X

[6] J. Jezkova, J. Musibva and K. Vytras, "Potentiometry with Perchlorate and Fluoroborate Ion-Selective Carbon Paste Electrodes," Electroanalysis, Vol. 9, No. 18, 1997. pp. 1433-1436. doi:10.1002/elan.1140091813

[7] M. Shamsipur, A. Soleymanpour, M. Akhond, H. Sharghi and M. A. Naseri, "Iodide-Selective Carbon Paste Electrodes Based on Recently Synthesized Schiff Base Complexes of Fe(III)," Analytica Chimica Acta, Vol. 450, No. 1-2, 2001, pp. 37-44. doi:10.1016/S0003-2670(01)01380-0

[8] M. N. Abbas and G. A. E. Mostafa, "Gallamine-Tetraphenylborate Modified Carbon Paste Electrode for the Potentiometric Determination of Gallamine Triethiodide (Flaxedil)," Journal of Pharmaceutical and Biomedical Analysis, Vol. 31, No. 4, 2003, pp. 819-826. doi:10.1016/S0731-7085(02)00663-5

[9] K. I. Ozoemena, R. I. Stefan, J. F. Van Staden and H. Y. Aboul-Enein, "Utilization of Maltodextrin Based Enantioselective, Potentiometric Membrane Electrodes for the Enantioselective Assay of S-Perindopril," Talanta, Vol. 62, 2004, pp. 681-685. doi:10.1145/996566.996753

[10] K. Boguslawska, M. Cieplinski and A. Cyganski, Chemia 
Analityczna, Vol. 30, 1985, p. 281.

[11] U. Voelkopf, Z. Grobenski, R. Tamm and B. Weiz, "Solid Sampling in Graphite Furnace Atomic-Absorption Spectrometry Using the Cup-in-Tube Technique," Analyst, Vol. 110, No. 6, 1985, pp. 573-577. doi:10.1039/an9851000573

[12] Z. Grobenski, D. Weber, B. Weiz and J. Wolff, "Determination of Caesium and Rubidium by Flame and Furnace Atomic-Absorption Spectrometry," Analyst, Vol. 108, No. 1289, 1983, pp. 925-932. doi:10.1039/an9830800925

[13] K. Bibow and H. H. Mundal, "Gradient Centrifugation to Isolate Platelets for Determination of Trace Elements by Neutron-Activation Analysis," Clinical Chemistry, Vol. 36, 1990, pp. 1902-1905.

[14] D. H. Oughton and J. P. Day, "Determination of Cesium, Rubidium and Scandium in Biological and Environmental Materials by Neutron Activation Analysis," Journal of Radioanalytical and Nuclear Chemistry, Vol. 174, No. 1, 1993, pp. 177-185. doi:10.1007/BF02040345

[15] K. H. Theimer and V. Krivan, "Determination of Uranium, Thorium, and 18 Other Elements in High-Purity Molybdenum by Radiochemical Neutron Activation Analysis," Analytical Chemistry, Vol. 62, No. 24, 1990, pp. 2722-2727. doi:10.1021/ac00223a014

[16] T. S. Light, "Industrial Use and Applications of Ion Selective Electrodes," Journal of Chemical Education, Vol. 74, 1997, pp. 171-176. doi:10.1016/S0927-6513(96)00080-6

[17] S. S. Hassan, I. H. A. Bader, A. H. Kamel and M. S. Mohamed, "A Novel Poly(Vinyl Chloride) Matrix Membrane Sensor for Batch and Flow-Injection Determinations of Thiocyanate, Cyanide and Some Metal Ions," Analytical Sciences, Vol. 25, No. 7, 2009, pp. 911-917. doi:10.2116/analsci.25.911

[18] M. Arvand and S. A. Asadollahzadeh, "Ion-Selective Electrode for Aluminum Determination in Pharmaceutical Substances, Tea Leaves and Water Samples," Talanta, Vol. 75, No. 4, 2008, pp. 1046-1054. doi:10.1016/j.talanta.2008.01.001

[19] S. Y. Kazemi, M. Shamsipur and H. Sharghi, "LeadSelective Poly(vinyl chloride) Electrodes Based on Some Synthesized Benzo-Substituted Macrocyclic Diamides," Journal of Hazardous Materials, Vol. 172, 2009, pp. 68-73. doi:10.1039/b9nr00143c

[20] A. Shamsipur, S. Rouhani, H. Sharghi, M. R. Gangli and H. Eshgi, "Strontium-Selective Membrane Electrodes Based on Some Recently Synthesized Benzo-Substituted Macrocyclic Diamides," Analytical Chemistry, Vol. 71, No. 21, 1999, pp. 4938-4943. doi:10.1021/ac990167e

[21] S. S. Hassan, M. Amer, M. S. A. El-Fatah and A. M. El-Kasasy, "Membrane Sensors for the Selective Determination of Fluorouracil," Analytica Chimica Acta, Vol. 363, No. 1, 1998, pp. 81-87. doi:10.1016/S0003-2670(98)00062-2

[22] M. Ying, R. Yuan, Z. Q. Li, Y. Q. Song, G. L. Shen and R. Q. Yu, "Salicylate-Sensitive Membrane Electrode Based on Copper(II) Tetraaza[14] annulene Macrocyclic Com- plex," Analytical Letters, Vol. 31, No. 2, 1998, pp. 1965 1977. doi:10.1080/00032719808005278

[23] P. S. Ramanjaneyulu, P. Singh, Y. S. Sayi, H. M. Chawla and K. L. Ramakumar, "Ion Selective Electrode for Cesium Based on 5-(4'-Nitrophenylazo)25,27-bis 2-propyloxy)26,28-dihydroxycalix[4]arene," Journal of Hazardous Materials, Vol. 175, No. 1-3, 2010, pp. 1031-1036. doi:10.1016/j.jhazmat.2009.10.113

[24] M. R. Ganjali, P. Norouzi, M. Emami, M. Golmohammadi and A. Mouradzadegun, "Novel Cesium Membrane Sensor Based on a Cavitand," Journal of the Chinese Society, Vol. 53, 2006, pp. 1209-1214.

[25] A. Radu, S. Peper, C. Gonczy, W. Runde and D. Diamond, "Trace-Level Determination of $\mathrm{Cs}^{+}$Using Membrane-Based Ion-Selective Electrodes," Electroanalysis, Vol. 18, No. 13-14, 2006, pp. 1379-1388. doi:10.1002/elan.200603542

[26] R. Bereczki, V. Csokai, A. Grun, I. Bitter and K. Toth, "Crown Bridged Thiacalix[4]arenes as Cesium-Selective Ionophores in Solvent Polymeric Membrane Electrodes," Analytica Chimica Acta, Vol. 569, No. 1-2, 2006, pp. 4249. doi:10.1016/j.aca.2006.03.039

[27] S. Peper, C. Gonczy and W. Runde, " $\mathrm{Cs}^{+}$-Selective Membrane Electrodes Based on Ethylene Glycol-Functionalized Polymeric Microspheres," Talanta, Vol. 67, 2005, pp. 713-717.

[28] Y. Choi, H. Kim, J. Kwang Lee, S. Ho Lee, H. Bin Lim and J. S. Kim, "Cs ${ }^{+}$-Selective Membrane Electrodes Based on Ethylene Glycol-Functionalized Polymeric Microspheres," Talanta, Vol. 64, No. 4, 2004, pp. 975-980. doi:10.1016/j.talanta.2004.04.015

[29] S. Vlasselaer, W. D. Olieslager and M. D. Haut, "Caesium Ion Exchange Equilibrium on Potassium-Zinc-Hexacyanoferrate(II) $\mathrm{K}_{2} \mathrm{Zn}_{3}\left(\mathrm{Fe}(\mathrm{CN})_{6}\right)_{2}$," Journal of Inorganic and Nuclear Chemistry, Vol. 38, No. 2, 1976, pp. $327-$ 330. doi:10.1016/0022-1902(76)80419-8

[30] P. S. Ramanjaneyulua, A. N. Kumar, Y. S. Sayia, K. L. Ramakumar, S. K. Nayak and S. Chattopadhyay, "A New Ion Selective Electrode for Cesium (I) Based on Calyx [4] Arene-Crown-6 Compounds," Journal of Hazardous Materials, Vol. 205-206, 2012, pp. 81-88. doi:10.1016/j.jhazmat.2011.12.017

[31] M. A. A. Perez, L. P. Marin, J. C. Quintana and M. Y. Pedram, "Influence of Different Plasticizers on the Response of Chemical Sensors Based on Polymeric Membranes for Nitrate Ion Determination," Sensors and Actuators B: Chemical, Vol. 89, No. 3, 2003, pp. 262-268. doi:10.1016/S0925-4005(02)00475-6

[32] IUAC Analytical Chemistry Division, "Commission on Analytical Nomenclature," Pure and Applied Chemistry, Vol. 66, No. 12, 1994, pp. 2527-2536. doi:10.1351/pac199466122527

[33] Y. Umezawa, K. Umezawa and H. Sato, "Selectivity Coefficients for Ion Selective Electrodes: Recommended Methods for Reporting $\mathrm{K}^{\text {pot }}$ Values," Pure and Applied Chemistry, Vol. 67, No. 3, 1995, pp. 507-518. doi:10.1351/pac199567030507

[34] S. Kamata, A. Bhale, Y. Fukunaga and A. Murata, "Cop- 
per(II)-Selective Electrode Using Thiuram Disulfide Neutral Carriers," Analytical Chemistry, Vol. 60, No. 22, 1998, pp. 2464-2467. doi:10.1021/ac00173a700

[35] L. I. Antropov, "Theoritical Electrochemistry," Mir, Moscow, 1972.

[36] D. Wang and S. J. Shih, "Caesium Ion-Selective Electrode Based on 15-Crown-5-Phosphotungstic Acid Precipitates," Analyst, Vol. 110, No. 6, 1985, pp. 635-638. doi:10.1039/an9851000635

[37] G. F. Michael, M. David, S. M. William and D. G. Jeremy, "Caesium Ion-Selective Electrodes Based on Crowned Benzoquinones," Analyst, Vol. 121, No. 2, 1996, pp. 127131. doi:10.1039/an9962100127

[38] M. B. Saleh, "New Cesium Ion-Selective Electrodes Based on Anilino-(1,3-dioxo-2-indanylidene) Acetonitrile," Talanta, Vol. 46, 1998, pp. 885-895.

$$
\text { doi:10.1016/S0039-140(97)00334-2 }
$$

[39] B. N. Barsoum, S. K. Khella, A. H. M. Elwahy, A. A. Abbas and Y. A. Ibrahim, "Evaluation of Some New 14and 15-Crown-Formazans as Carriers in Cesium Ion Selective Electrodes," Talanta, Vol. 47, No. 5, 1998, pp. 1215-1222. doi:10.1016/S0039-9140(98)00204-5

[40] J. S. Kim, A. Ohki, R. Ueki, T. Ishizuka, T. Shimotashiro and S. Maeda, "Cesium-Ion Selective Electrodes Based on Calix[4]arene Dibenzocrown Ethers," Talanta, Vol. 48, No. 3, 1999, pp. 705-710. doi:10.1016/S0039-9140(98)00291-4

[41] H. Oh, E. M. Chio, H. Jeong, K. C. Nam and S. Jeon, "Poly(vinyl chloride) Membrane Cesium Ion-Selective Electrodes Based on Lipophilic Calix[6]arene Tetraester Derivatives," Talanta, Vol. 53, No. 3, 2000, pp. 535-542. doi:10.1016/S0039-9140(00)00531-2 